Journal of Management and Social Sciences

Vol. 9, No. 2, (Fall 2013) 31-41

\title{
Analysis of Internal \& External Factors Affecting Choice of Business Schools by Students
}

\author{
Rizwana Bashir* \\ Bahria University, Karachi Campus \\ Atif Hassan* \\ DHU Suffa University, Karachi \\ Muhammad Ali Pasha* \\ University of Sindh Jamshoro \\ Shoaib Ahmed* \\ Institute of Business \& Technology Karachi
}

\begin{abstract}
Purpose - With the changing trends business studies have become very popular amongst the students as a means of future career. Accordingly, an issue has always been at hand the students and parents both that which higher education institution be selected for the business management education. This research paper examines different factors that influence business student's behavior in selecting a business school.

Methodology/Sample - The research has been carried out in the vicinity of Karachi city. The researchers used both primary and secondary methods of data collection. Primary data was collected through questionnaire. The sample of 100 students was selected. Probability sampling technique was used whereby 10 students were selected form each well known business schools of Karachi.

Findings - The researcher classified different influencing factors into two main categories -- internal and internal ones and found that both internal and external factors influence business students in selecting a business school but external factors influence students more than internal factors.

Practical Implications - The outcome of the research guide the future business management students about quality and standards of various business schools as well as assist the business school in identification of the factors critical for the students.
\end{abstract}

Keywords: influencing factors, business students, business schools, Karachi.

\section{Jel Classification: I21, I25, M10}

\footnotetext{
*The material presented by the authors does not necessarily portray the viewpoint of the editors and the management of the Institute of Business \& Technology (IBT)

* Rizwana Bashir: rizvvana@gmail.com

*Atif Hassan: atif.hassan@ dsu.edu.pk

* Muhammad Ali Pasha: muhammadalipasha@gmail.com

*Shoaib Ahmed: shoaib.ahmed@ibt.edu.pk

CJMSS is published by the Institute of Business and Technology (IBT).

Main Ibrahim Hydri Road, Korangi Creek, Karachi-75190, Pakistan.
} 


\section{INTRODUCTION}

There are many kinds of students like medical students, engineering students, arts students, etc. Business students are those students which are learning business courses like MBA, BBA, etc. The business students are those who obtained a university degree in Business Administration. They obtained degree in Business Administration with major courses in human resource management, finance, marketing, supply chain management, etc. These students after obtaining degree start their careers in business world.

Business schools are those institutes that give business studies to the students. In Karachi there are many business schools. These schools can also be known as a business college, college of business, college of business administration, school of business, school of business administration, or, colloquially, b-school. The courses that are taught at business school includes accounting, administration, strategy, economics, entrepreneurship, finance, human resource management, information system, marketing, organizational behavior, public relations, research methods, etc. According to HEC there are public sector business schools and private sector business schools in Karachi.

These are the factors that influence student's choice decision while selecting business school. These includes location, image, faculty, research opportunities, industry linkages, collaboration with foreign universities, scholarships, word of mouth, peer pressure, parents pressure, marketing, fee structure, etc.

In the current century a much emphasis is given on selecting a career. Both parents and students jointly make planes for future. After done with this problem another important problem arises that is from where to get the education. Like many students choose subjects to which they don't have any interest just because to please their parents' wishes. Same is the case with selecting educational intuitions. Many students are unaware why they have selected any institute. There is a perception that they only consider the reputation of the institute. This research tries to identify different factors that influenced business students while selecting a business school. This research examine on what ground students decision is based. If getting business education is their objective then they can get it from any business school why they select a particular business school.

This research is of great significance for both the business students and business schools. This research helps the business students to understand why they have selected any business school, what advantages they can enjoy and what they cannot if they got admission in any business school. From the business schools point of view this research help them to understand the needs and demands of the students and they can increase their productivity and profitability and capture large market share in the market. It also helps them to compete with their competitors. As there are number of business schools in Karachi therefore, this research helps business schools how to attract students, to work out on those factors in which they are not efficient and to understand which factor student value the most while selecting business school.

For this research some internal and external factors are taken as independent variables while the decision to take decision is taken as dependent variable. Internal factors comprised:

- Family

- Peer advice

- Friends

- Association with institute

- Advertising

- Word of mouth

Whereas external factors included:

- Location

- Fee structure

- Faculty

- $\quad$ HEC Ranking 
- Scholarships

- Collaboration with foreign universities

- Grading Method

- Courses Offered

- Industry linkages

- Research opportunities

- Facilities

\subsection{Hypotheses}

$\mathrm{H}_{1}$ : Internal Factors influence business student's decision while selecting business school

$\mathrm{H}_{\mathrm{A}}$ : Internal Factors does not influence business student's decision while selecting business school

$\mathrm{H}_{2}$ : External Factors influence student's decision while selecting business school

$\mathrm{H}_{\mathrm{A}}$ : External Factors does not influence business student's decision while selecting business school

$\mathrm{H}_{3}$ : Internal Factors influence students more than the External Factors.

$\mathrm{H}_{\mathrm{A}}$ : External Factors influence students more than the Internal Factors.

\section{LITERATURE REVIEW}

Ming (2010) did a research in Malaysia. The researcher found different factors that influence student's behavior in selecting a college. The research has found two broad factors then he further found different factors inside in these factors. The first factor is "Fixed College Characteristics" and the second factor is "College Effort to Communicate with Students"'. In "Fixed College Characteristics" he further found the factors of location, academic program, college reputation, educational facilities, cost, availability of financial aid and employment opportunities. In second factor he discovered the factors of advertising, Higher Education Institutions representatives and campus visit. Ming (2010) inresearch shows that these two factors influenced students' college choice decision in Malaysia.

Saeed \&Ehsan (2010) conduct the research and found the six most important factors that play an important role in branding the business school in Pakistan. These six factors are Name of the University, Research opportunities, Qualification of Faculty, Research of Faculty, Designing (Logos, color scheme etc.), Allied resources.

Mudholkar (2012) conduct research in Mumbai. The researcher found 15 student's choice factors for selecting business school. According to his findings these factors are placement, image/reputation, infrastructure, specialization, faculty, peer advice, fees structure, alumni base, location, accreditation, hostel facility, financial aid, industry link, research activities and collaboration with foreign institutes. Research found that there is a difference in male and female student's choice factors. According to research male students are more influenced by the factors of placement, image/reputation, infrastructure, specialization and faculty. Whereas, female students considers these factors image/reputation, faculty, fees structure, location and placement. Mudholkar (2012) states that placement, image/reputation and faculty are most important student's choice factors where as industry link, collaboration with foreign institutes and research activities are least choice factors.

Shahid, Shafique and Bodla (2012) did a research on factors affect a student's choice of a university. The research is done in LUMS. They found three factors that student's consider in selecting university. These are reputation of institute, word of mouth and marketing communication. Their research revealed that Word of Mouth has a very deep impact on student's choice of a university. According to them the most important factor is peer pressure and environment. The least important factor they found is generic marketing communication (advertisement). According to researchers students don't require advertisement from well known universities like LUMS.

Ijaz, Irfan, Shahbaz, Awan and Sabir (2011) conducted research and found that public sector business schools are providing better quality of education and students are 
more satisfied with them. Students graduated from these business schools have good job opportunity in market. Moreover, infrastructure, well educated and experienced faculty, low fee structure, scholarships opportunity and good reputation influenced students to take admission in public sector business schools as compared to private sector business schools. The researchers further found that quality of education is the most important factor. The researchers found six factors these are Tangible, Reputation, Cooperation and support, Reliability, Responsiveness and Student satisfaction.

\section{RESEARCH METHOD}

The researcher has selected questionnaire approach in order to collect primary data from business students. The questions included both close-ended with multiple choices for answer selection and open-ended to collect the responses. This method will help the researcher to analyze the problem deeply.

Business students are the target population for this research. The business students of different business schools of Karachi are selected to answer the questionnaire. This research involves two samples. The first sample is to select business schools and then select business students from these schools to fill the questionnaire. Researcher selected the sample size of 10 business schools and researcher selected the sample size of 100 business students.

Researcher used the technique of probability sampling and selected simple random sampling method. Out of 20 Higher Education Commission (HEC) recognized universities (appendix 1.1) in Karachi 10 are selected. These10 business schools are Institute of Business Administration (IBA), BAHRIA University Karachi Campus, IQRA University, Shaheed Zulfiqar Ali Bhutto Institute of Science and Technology(SZABIST), Institute of Business Management (IoBM), HAMDARD University, Jinnah University for women, Commeces Institute of Business \& Emerging Sciences, Institute of Business \& Technology (IBT) and University of Karachi (UoK). For selecting the business students to fill questionnaire researcher used non-probability sampling technique. The convenience method is used to select first 10 business students from the selected business school.

In order to collect secondary data different sources used which includes journals, publications, research papers, websites etc available online. Primary data is collected through the questionnaires filled by the business students.

100 students are selected from 10 business schools of Karachi through probability simple random sampling method. The name of these business schools are Bahria, Iqra, IBA, SZABIST, University of Karachi, Commeces, IoBM, IBT, Jinnah University for women and Hamdard University. All selected business schools are given equal representation. Out of 100 business students 49 are from BBA 46 students are from MBA and 5 students are students of other business studies. The total number of males and females responded to questionnaire is 100 . There were 50 females and 50 males participated in the survey from different business schools and studying different business courses (MBA/BBA).

\section{DATA ANALYSIS}

The nature of this research is Quantitative. The data is collected online through questionnaire. After collecting data from students through online the researcher entered it in MS excel worksheets. There were total 13 questions in the questionnaire and every question's responses were analyzed. The analyses are as follows:

\subsection{Total Business Schools Applied For}




\section{\# of Business schools applied}

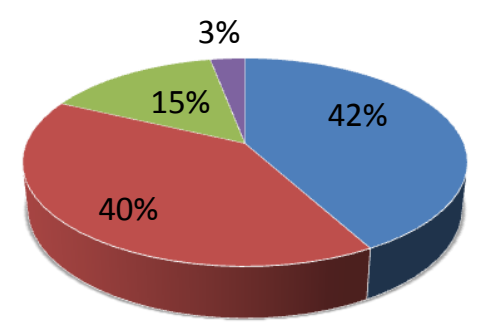

From the collected data it is shown that mostly students applied in 1 to 2 business schools only. They have only chosen 2 options and gave those business schools aptitude tests. Some of the students also applied in 3 business schools and a very few students applied in 4 business schools. According to analysis $42 \%$ of the respondents applied in 1 business school, $40 \%$ of the respondents applied in 2 business schools, $15 \%$ of the respondents applied in 3 business schools and only $3 \%$ applied in 4 business schools.

\subsection{Reason for Selecting Business School}

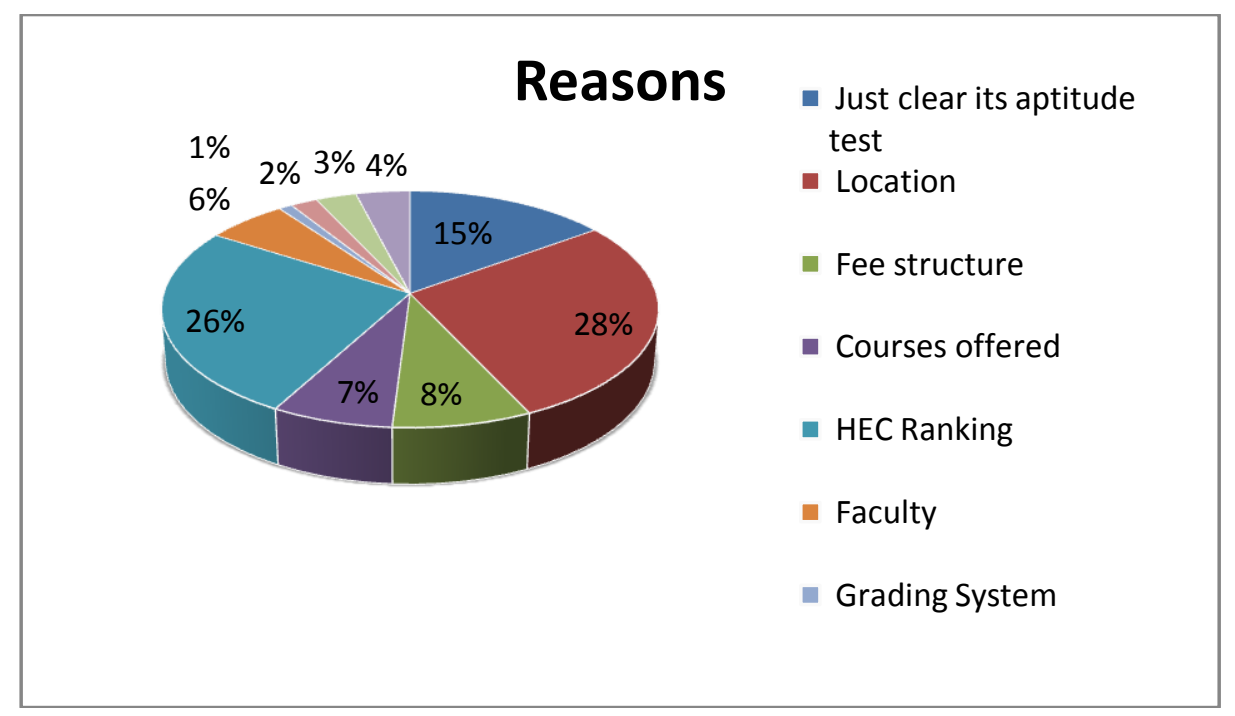

The data shows that most of students select university because of two reasons. First, the location of business school and second is the HEC ranking of the business school. After these two reasons another reason why students selected a particular business school is that they have just only cleared those business schools aptitude test. According to the research $28 \%$ of the students selected their business schools because of their Location, $26 \%$ because of HEC Ranking, $15 \%$ because they have just only cleared those business schools aptitude test, $8 \%$ because of Fee structure, $7 \%$ because of Courses offered, $6 \%$ because of Faculty of the business school, 4\% because of Industry Linkages, 3\% because of Collaboration with foreign universities, $2 \%$ because of Scholarships and $1 \%$ because of Grading Method of the business school. 


\subsection{Internal Factors Influence on Student's Decision}

\section{Internal Factors Influence}

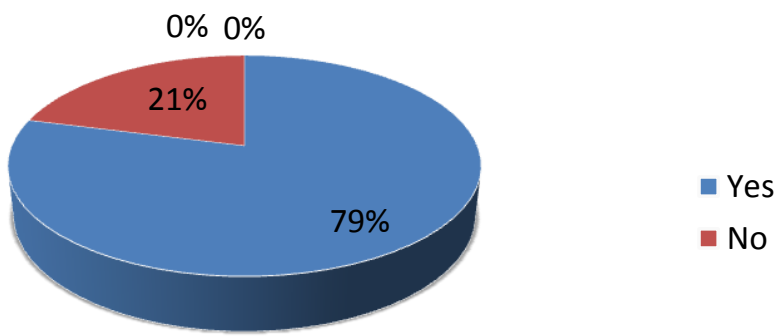

The data shows that mostly students consider internal factors such as family, friends, peers advice, advertisement, word of mouth and past association while selecting a business school. They think that internal factors influence their decision in selecting a business school. Out of 100 respondents 79 respondents are in favor that internal factors influence them in selecting a business school while 21 respondents think that internal factors does not influence them in selecting a business school.

\subsection{Most Influencing Internal Factor}

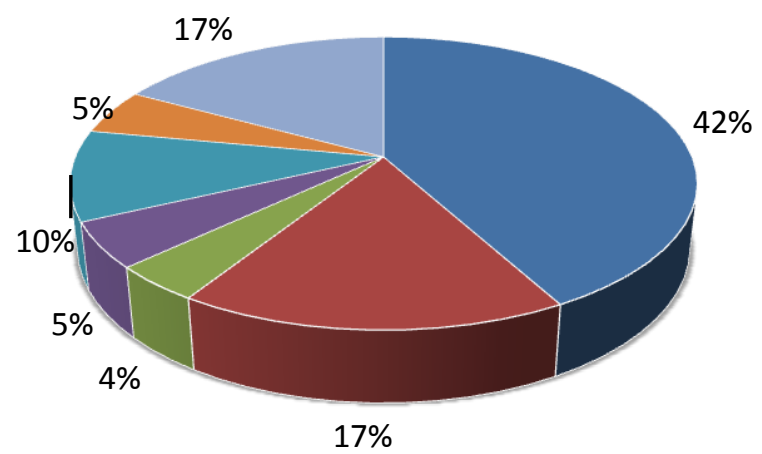

- family

no response

peers advice

- advertisement

word of mouth

past association

- friends

After the analysis of data it is shown that family is the most influencing internal factor. Majority of students selects business school according to their parents' wishes. After family friends is the second most influencing internal factor. Students select business schools because their friends are going to take admission there. After friends word of mouth is the third most influencing internal factor. Other factors such as past association, advertisement and peers advice have very low influence on students in selecting a business school. Out of 100 respondents 42 answered that family is the most influencing internal factor for them, 17 answered friends, 10 answered word of mouth, past association and advertisement are answered by 5 respondents each, 4 answered peers advice and 17 respondents did not answer this question. 
4.5 External Factors' Influence on Student's Decision

\section{$0 \% \quad 0 \%$ External Factors Influence}

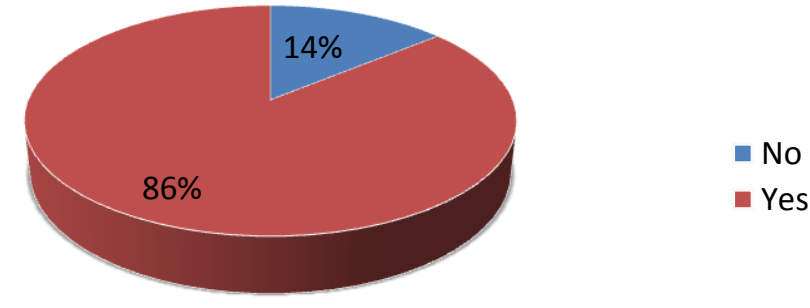

The data has shown that external factors play an important role in selecting a business school. Students give priority to the external factors in selecting business schools. $86 \%$ of the respondents are in favor that external factor influence their decision while only $14 \%$ of the respondents are against it they think that external factors does not influence them in selecting a business school.

\subsection{Most Influencing External Factor}

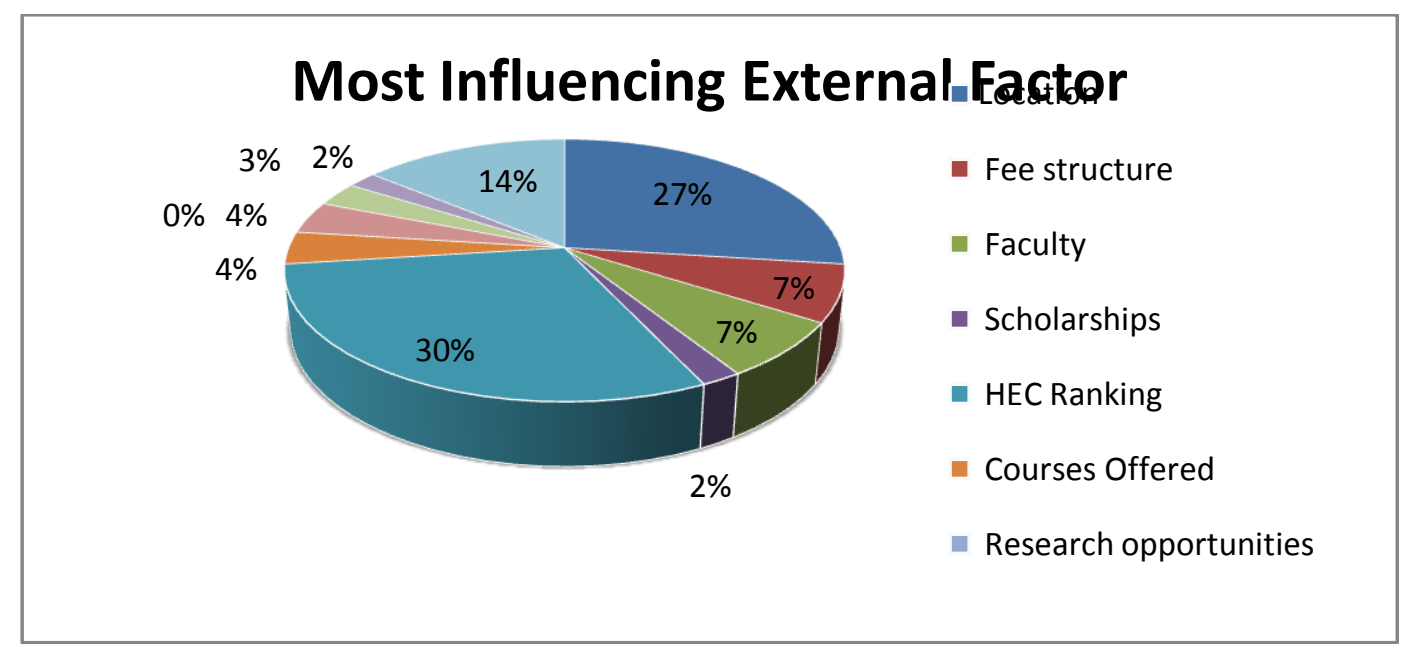

The research has shown that HEC Ranking of the business school is the most influencing external factor. According to research $30 \%$ students are influenced by the HEC ranking of the business school. After HEC ranking the second most influencing external factor is Location of Business School. 27\% students are influenced by the location of the business school. After these two factors then come Fee Structure and Faculty of business school. 7\% students are influenced by these factors each. According to research $4 \%$ are influenced by Industry Linkages, $3 \%$ by Collaboration with foreign universities, $2 \%$ by grading method and $2 \%$ by Scholarship. $14 \%$ of the respondents did not answer this question. 


\subsection{External v/s Internal Factors}

\section{External v/s Internal Factors}

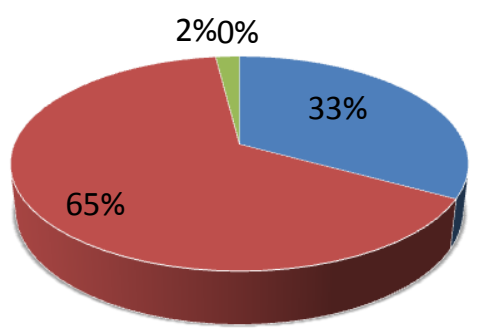

No

Yes

No response

The data has shown that external factors such as location, HEC ranking, fee structure, faculty, etc influence business students decision of selecting a business school more than internal factors such as family, friends, peers advice, past association, word of mouth and advertisement. Out of 100 respondents 65 answered that external factors influence them more than internal factors in selecting a business school, 33 of the respondents answered that external factors does not influence them more than internal factors and 2 of the respondents did not answer this question.

\subsection{Most Influencing External and Internal Factors}

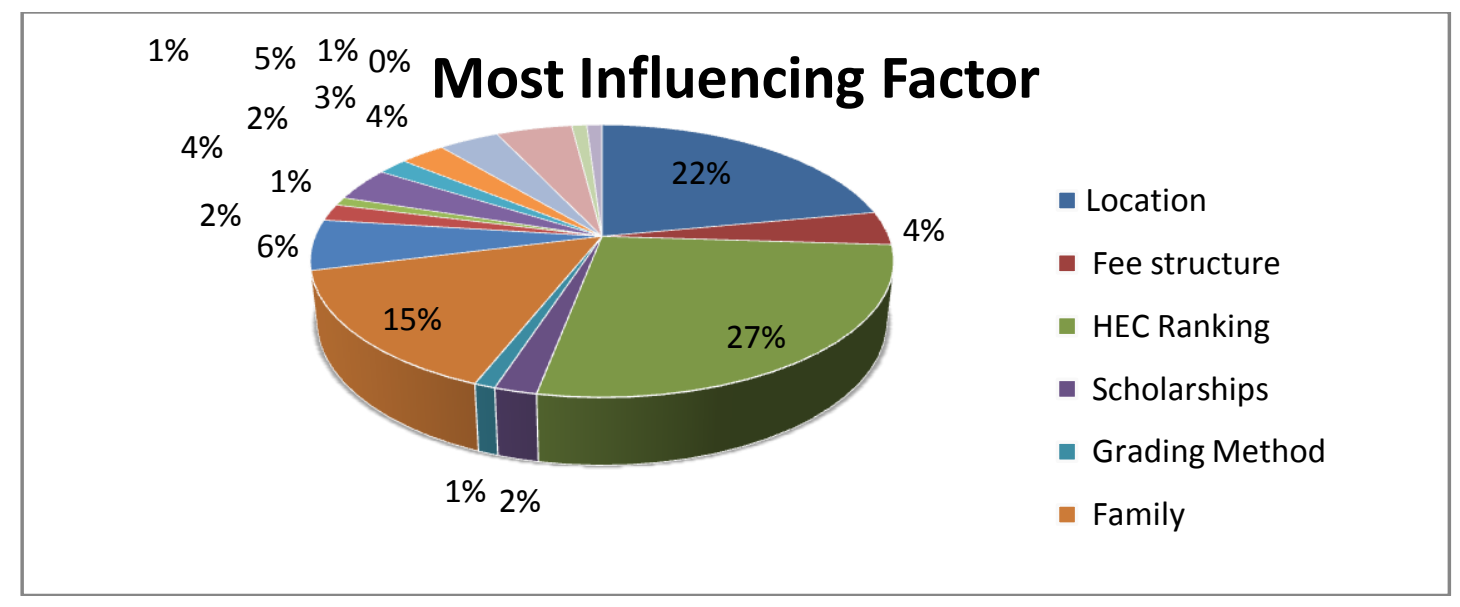

After analysis it is found that HEC ranking and location of business school are the most influencing external factors. Students before applying in any business school first consider these two external factors. While family opinion happens to be the most influencing internal factor. Family opinion plays an important role in selecting a business school. According to data it is found that 27\% HEC ranking, 22\% Location, $15 \%$ Family, $6 \%$ Friends, 5\% courses offered, $4 \%$ Word of mouth, $4 \%$ Faculty, $4 \%$ Fee structure, 3\% Past association, 2\% Peers advice, 2\% Industry Linkages, 2\% Scholarship, $1 \%$ Facilities, $1 \%$ Grading Method, $1 \%$ Advertisement and 1\% Research opportunities influence business students in selecting a business school. According to research Collaboration with foreign universities have no influence on students decision. Therefore, it is found that HEC Ranking, Location and Family are the most influencing factors in selecting a business school.

\subsection{Satisfaction with the Decision}




\section{Satisfaction with decision}

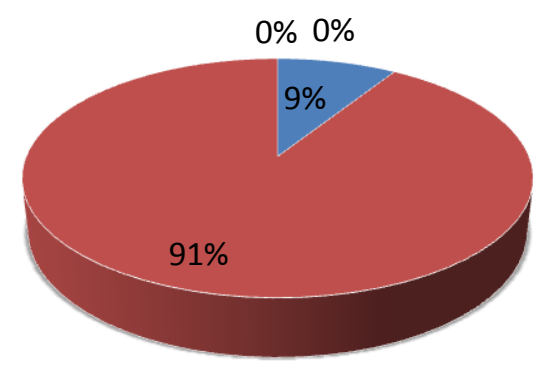

The data has shown that mostly students are satisfied with their decision of selecting a business school. They are happy with their decision. They believe that they have made a right decision. Only few students are not happy or satisfied with their decision. The analysis has shown that $91 \%$ of students are happy with their decision only $9 \%$ are not happy with their decision.

\section{DISCUSSION \& CONCLUSION}

After completing the research and analyzing the data the researcher has found that null hypothesis one $\mathrm{H} 1$ which is "internal factors influence business students in selecting a business school" is accepted and its alternate hypothesis which is "internal factors do not influence business students in selecting a business school" is being rejected.

Similarly, research has proved that null hypothesis two $\mathbf{H 2}$ which is "external factors influence business students in selecting a business school" is accepted and its alternate hypothesis which is "External Factors does not influence business students in selecting a business school" is false and being rejected.

The research has also proved that null hypothesis three $\mathbf{H 3}$ which is "internal factors influence students more than External Factors" is false and being rejected and its alternate hypothesis which is "External Factors influence students more than Internal Factors" is accepted.

From the research it is proved that both internal and external factors influence business students in selecting a business school in Karachi. The findings of the research also showed that external factors influence business students' more than internal factors. It is also found from the research that family is the most influencing internal factor then followed by friends and word of mouth. The research also shows that the most influencing external factors are location and HEC ranking of the business school which is followed by fee structure, faculty and industry linkages.

The research also found that the majority of the students are satisfied with their business school decision. Therefore, it is concluded that the most influencing factor is HEC ranking of the business school. The factors influencing most business students in selecting a business school in Karachi are HEC ranking, Location, Family, Fee structure, Faculty, Friends and Past association with business school. Other factors such as Scholarships, Grading Methods, Courses offered, Advertisement, Word of Mouth, Industry Linkages and Research opportunities have very low influence on business students decision.

Therefore, it is concluded that H1 which is "Internal Factors influence business students in selecting a business school" is accepted and its alternate hypothesis is being rejected. Similarly, $\mathrm{H}_{2}$ which is "External Factors influence business students in selecting a business school" is accepted and its alternate hypothesis is rejected. For $\mathbf{H 3}$ which is "Internal Factors influence students more than External Factors" is rejected and its alternate hypothesis which is "External Factors influence students more than Internal Factors" is accepted. 
In this research the researcher has grouped various factors into two main groups which are internal and external factors and their impact on business student's decision while selecting business school in Karachi. It is therefore, recommended for future researchers to study the impact of each factor grouped in internal and external factors to gain the further insides and deep understanding of their separate impact on business students. Moreover, it is also recommended for future researchers to study the whole Pakistan's business students because this research is only done in Karachi.

\section{REFERENCES}

1. Ijaz, A. , Irfan , S.M. , Shahbaz, S. , Awan, M. andSabir, M. (2011). An Empirical Model of Students Satisfaction: Case of Pakistnai Public Sector Business Schools.

Journal of Quality and Technology Management, [online] Available at <http://pu.edu.pk/images/journal/iqtm/PDF-FILES/06-Student_Satisfaction.pdf> [Accessed on 11 March 2013].

2. Ming, J. S. K. (2010). Institutional Factors Influencing Students' College Choice Decision in Malaysia.International Journal of Business and Social Sciences, [online] Available at <http://www.ijbssnet.com/journals/Vol._1_No._3_December_2010/6.pdf> [Accessed on 1 March 2013].

3. Mudholkar, D. B. S. (2012). A Study Student's Choice Factors for Selecting BSchools with Special Reference to Mumbai. Zenith International Journal of Multidisciplinary Research, [online] Available at <http://www.zenithresearch.org.in/images/stories/pdf/2012/April/ZIJMR/8_ZIJMR _APRIL12_VOL2_ISSUE4.pdf > [Accessed 5 March 2013].

4. Saeed, M. K. \&Ehsan, U. (2010). Exploring the Most Important Factors while Branding the

5. Business Schools.Journal of Management and Social Sciences, [online] Available at

<http://www.biztek.edu.pk/downloads/research/jmss_v6_n1/5.CREATING\%20BR ANDED\%20ADVANTAGE.pdf $>$ [Accessed on 4 March 2013].

6. Shahid, H., Shafique, O. and Bodla O.H. (2012). What Factors Affect a Student's Choice of a University for Higher Education.Research on Humanities and Social Sciences, [online] Available at <www.iiste.org/Journals/index.php/RHSS/article/download/.../3407> [Accessed on 8 March 2013 ] 